\title{
The Influence of Ancient Rus Religious Art Elements on Russian Modern Paintings
}

\author{
Lin Shen \\ Art College, Shandong Women's University \\ Jinan, Shandong \\ e-mail: shen20061109@163.com
}

\begin{abstract}
Based on the first-hand materials collected when he studied in Moscow State Surikov Academy of Fine Arts, the author undertakes the research on the historical evolution, artistic connotation and the formation of Russian traditional Orthodox art. From the perspective that the root of Russian art lies in the national feelings and the artistic spirit bred by orthodox culture, this paper aims to analyze its influence on modern culture and contemporary value so as to expand research perspectives of the Russian art and enlighten the connotation of in-depth study.
\end{abstract}

Keywords-Russia; nationality; orthodox culture; modern influence

\section{INTRODUCTION}

Traditionally people regard the development process of Russian art as the branch of European art, which is influenced by various western cultures in different periods of history. It is indeed so superficially. However, when you probe into Russia spiritually, you will find that Russian fines art progress is in an effort to get rid of foreign influence. The fulcrum is the nationality, in other words, it is the orthodox culture and traditional folk art that exert great influence on the constitution of its nationality.

Ancient Rus church was firstly built in Kiev in tenth Century. In the "golden age" of ancient Rus art in 14---15 century, Greek Feofan Greco was the representative of this style. By fifteenth Century, local painters in large numbers sprang up and the Russian national painting school eventually formed in Moscow. The most outstanding representative is Andrey Roublyov. The ancient Russ orthodox art had experienced the introduction and fusion of Byzantine Empire, and then formed its national style. By the late fifteenth Century, local painters represented by Gionis came to a successful conclusion. In seventeenth Century, the ancient Russian architectural style featured by "Moscow Baroque" came to an end and since then, the orthodox art fused with and penetrated into secular painting and gradually got separated from it. The Westernization eventually won the victory over Byzantium in the intensifying confrontation. After eighteenth Century, along with reformation of Peter the Great, Orthodox tradition art had been away from the Byzantine Church spirit and that of ancient Rus, and replaced by classical, practical and secular style.
Any art form has its own law of development and the rise and fall. When its dominant function declines, the implicit value is increasingly remarkable. Its significance and influence often go beyond the art itself.

Travelling in Moscow, Modern painting pioneer Matisse appreciated the orthodox art and lamented: "This is the real national art with the origin of the artistic exploration. Modern artists should derive the inspiration from these ancient arts." "Some excellent orthodox murals, icon painting of Ancient Moscow and Novgorod not only proved the long history of Russian national culture, but also demonstrated its greatness." In his reply to the question that what impression the ancient Russian art left on him, he said that the Russians even had not expected that they had so much rich artistic wealth. More and more young people can enjoy the most excellent and incomparable foreign art examples in their own country. French artist ought to come to Russia to study. Italy has been just a little bit worse in this regard." In terms of the depth of painting spirit and language expression, Matisse revealed the things that even the Russians were not clearly aware of at the time with his insight and sensitivity.

At the beginning of twentieth Century, at the same time that the Russian artists comprehended its ethnic and religious spirit, they also began to feel its artistic connotation, which was the aesthetic significance of forms as well as materials and techniques, and created an opportunity for a new pattern of Russian modern and contemporary art.

In contemporary Russia, nearly eighty percent of people believe in orthodox, which occupies a special position in the Russian social life and ideology. Russia is experiencing a revival of religion. The new construction, reconstruction and restoration of the church are in head way, which makes much essence of Russia's ancient culture and the Byzantine artistic style got inherited in whole, becoming the living fossil for people to understand the ancient religious art. As Russia had not experienced the baptism of European Renaissance, such essence of the medieval religious art which lasted until today in its original form provides abundant historical materials for artistic creation, college teaching and academic research. 


\section{THE INFLUENCE OF ORTHODOX ARTISTIC ELEMENTS ON RUSSIAN MODERN PAINTINGS}

In nineteenth Century, many painters bosomed different understanding of the orthodox spirit and started the creation about religion. The realistic interpretation of religion by itinerants russia was one of the important reasons causing the attention and controversial of the people at the time. As a historical painter, Barenov was proficient in Bible and at the same time, he undertook deep study of Biblical Archaeology and Jewish culture. In his religious paintings, what happened in the Bible matched with historical and geographical knowledge. In his painting "who is not guilty", the characters' clothing, landscape of holy land and daily necessities were all testified by the "Biblical Archaeology".

On the halfway from Moscow to Sergi St. Trinity Monastery, the Abramtsevo estate of Mamontov who was the famous literature and art patron wass located there. In the second half of the nineteenth Century, a group of famous Russian painters and musicians gathered here who were engaged in artistic activities related to ethnic, religious and traditional culture. "It is full of the spirit of Rus and the breath of Rus here." The painter Barenov described the manor atmosphere with the words of Pushkin. The orthodox spirit, national history, legends and folk art here become artists' origin of creation. Arts and crafts of "Russian style" created by the carpenter shop run by the Vasnetsov and pottery workshop run by Vrubel were of great influence and collected as the exceptional art works by people. A small Orthodox Church was constructed in Mamontov garden, which marked an important moment, namely the moment that orthodox tradition was inherited by Russian artists in the late nineteenth Century. Mamontov decided not to hire an architect. The painters Vasnetsov, Repin, Barenov and him assumed the missions of designing and decoration. Carving patterns was undertaken by Barenov. Mosaic floors were paved according to Vasnetsov's religious works. Vrubel made tiles-veneered fireplace. Repin's painting of "Christ" was like the shroud of Turin, simple and dignified, naturally created, full of mysteries, becoming the spiritual symbol of the church.

Known as the "Russian Rafael", Vasnetsov presided over the drawing of "Almighty Christ" series of paintings in the Kiev Vladimir church. The new image of murals was repeatedly copied as template. Vrube left the Academy of Fine Arts in 1884 and began the restoration and repair drawing works of Kirillov cathedral in Kiev. He had spent long time studying the spiritual connotation and pattern characteristic of Byzantine art as well as the unique color beauty of the church mosaic, which achieved the artistic style combining his religious spirit, national sentiment and mysterious personality, opening the access to the modern Russian art. The painter Nesterov which was active before and after the revolution of October was with a certain mysterious religious spirit and national complex. He was born in a deeply religious orthodox family and developed vegetarian habit. He did not describe the plot of "Bible" directly, but involved religious spirit and emotion in paintings. His representative work of "Juvenile Bartholomew" was regarded by artist Nua as "one of the most religious poetry and wonderful paintings pathos in the last ten years nineteenth Century."
At the beginning of the twentieth Century Moscow was the most exciting place for the artists of the world. It was the natural place for the cooperation between artists and radicalism, the regeneration place for Russian culture. The avant-garde art had become the most beautiful landscape of Russian culture in this period. In 1910, the exhibition entitled " Prince Diamond" was held in Moscow. The three books painted as the props in Mashkov's "Self-portrait with Peter" revealed the "mystery of modern Russian style: the book for "Cezanne" represented the impact of European modern paintings on Russia; the book of "Bible" implied the Russian religious spirit and the root of Slavonic nationality; the book of "Art" symbolized that the art achieved the inversion of "modern art" with the help of these two elements.

Kandinsky seemed never to have his art associated with orthodox, even in his book of "On Art Spirit". However, on the trip to the Floygrada in northern Russia, he wrote in his diary: "I was shocked at the door. Tables, stools, huge stove and cupboards were full of bright-colored original pattern. I found myself surrounded by walls of picture and felt myself also a part of the picture." In Moscow, he saw the churches in a fairy tale, which made him experience the illusion of old Russia, which he later experienced in the Bavarian church again. He believed that the production of works of art was like the formation of universe needing to experience the chaos and catastrophe and only born out of "sounds of nature". In his spiritual kingdom, there was always a mysterious core, which he contributed to Russian aesthetics, as was shown in his "Legend of Russia" "Saints" and "Series of Construction".

In 1969 the French Ministry of culture decided to build "national Chagall" Bible "message Gallery" in Nice. In his late years, Chagall lived a life of recluse on St Paul hill in Brunei in southern France. The diligent painter was like a saint and never ceased to explain the "Bible". He worked for thirty years for "the Bible" illustrations, which was the best interpretation of his life and art. He timely conveyed the "Bible" message. Chagall's cabin, flowers, calf, candlestick, churches and those dreamlike flying lovers brought people into the mural atmosphere of Russian medieval cathedral and the mystery of Russian folk tales. Poetry, God and children constructed Chagall's supernatural spiritual yearning and sacred art. $\mathrm{He}$ said: "In the realms of theology and religion, I am enlightened."

The beginning of Malevich's paintings attributed to the icon painting and Chapel frescoes. He said: "In my early stage of painting, I just imitated icon painting and attempted to combine icon painting with folk art." In early twentieth Century the "Wet Mural drawing", "Christ's shroud" and other works were the variants of the church murals. He said: "The study of icon art has convinced me that it is not the question of learning anatomy or perspective, nor the question of restoring the natural truth, but the artistic intuition and ability of experiencing the reality of artistic reality." From his "Harvest Woman" painted in 1912 which was of cubism tendency, the influence of the woman image in the dry mural in JaRuslav cathedral on him can be seen clearly. He created the "black diamond" of "supremacy" which was a sacred relic hint, known as an icon which was not accepted by people but by the 
revolution. He said: "My black diamond is a naked frameless icon of our time."

Tatlin was known as the "founder of constructivism". This was not only because he created the famous "Monument to the Third International" in 1920, but also he advocated nonutilitarian constructivist art in 1917. In 1883 he began his art career by the icon painting and studied painting in icons drawing room in Moscow and JaRuslav. He had taken Russian traditional art including fresco as the source of inspiration for creation. The critic Nicola Puning, the colleague of Tatlin's said: "The influence of Russian folk art on Tatlin would be undoubtedly greater than that on Cezanne or Picasso." The sculptor and critic Mavit pointed out: "the resonance of color, sound of materials, and combination of texture lead people to beauty, religion and God. The real world is achieved by the real, concrete objects and mosaic, $\cdots$ - • orthodox art spirit and decorative material character are undoubtedly implied in Tatlin's "modern abstract art."

In 1991 the Soviet Union disintegrated and political consciousness in art gradually disappeared. Artistic pluralism was taken as the standard brought into the field of painting. A new generation of artists sprang up rapidly and they were the generation of free artists. They broke away from the former Soviet Union's "mainstream culture" and also got tired of using others' language to express their national theme. They were seeking in the ruins. They thought that the creation of artists not only depended on the real image, but on the "civilized feelings"; it not only paid attention to the nature, but also the spirit. This expression must be achieved through thinking and imagination, combining personal exploration with cultural tradition as well as the eternal value. They tried to build the aesthetic value of the ontology of art, deepened the spiritual connotation of art, trying to find the art style which can exist independently and a new, extremely localized art without the ideology.

\section{CONCLUSION}

One characteristic could be found by the analysis of the modern and contemporary Russian art trend and style that in the rising trend of the nationalism and religious revival, they realized that there was great potential influence of the national spirit, the orthodox culture and folk art on the formation of new art. Despite their different pursuits, understanding and expression forms, they'd made the same efforts in the pursuit of modernization, internationalization, individualism and diversification and at the same time, tried to get them fused with more national, religious and traditional elements as well as the real feelings and the natural ecological concept so as to build the basic framework of the Russian contemporary art value system.

Researches on the Russian Orthodox artistic value and its cultural influence has reference value and practical significance for a comprehensive understanding of Russian art and its value orientation; for expanding and updating research paths of the progress of Russian art history and art creation; for reflecting on the gains and losses of the studies of Russian art; for exploring Chinese art creation and theoretical study of how to inherit ethnic and folk cultural heritage.

\section{REFERENCES}

[1] Florovski, Georgy. Translated by Wu Andi. Russian Religious Road[M].Shanghai Century Pubishing House. 2006.8.

[2] Sergeyevich Urie, Ryabtsev. Translated by Zhangbing, Wang Jiaxing. Russia of Thousands of Years [M]. SDX Joint Publishing Company. 2007.11.

[3] M.P.Zezyna. Translated by Liu Wenfei, Suling.The History of Russian Art[M]. Shanghai Translation Publishing House.2005.7.

[4] Xi Jingzhi. Art History of Russia and Soviet Union[M]. Tianjin Fine Arts Press. 2000.1

[5] "Annunciation Cathedral of Moscow kremlin" About 500 years unique anniversary. I. YA. Kachalova, N.A. Mayasova, L.A. Shchennikova, Art Moscow1990.

[6] "Ancient Rus PAINTING Mosaic murals ikons" A.A.edytseva M.K.Karger N.I.Kresalyny 1991. 